\title{
OBSERVASI KLINIK POTENSI JUS PISANG KEPOK (MUSA PARADISIACA L.) SEBAGAI ANTIHIPERTENSI PADA GERIATRIK
}

\author{
Rafika Hasdina*, Yuspian Nur, Laode Rijai \\ Laboratorium Penelitian dan Pengembangan Kefarmasian "Farmaka Tropis", \\ Fakultas Farmasi, Universitas Mulawarman, Samarinda, Indonesia \\ *Email: din4f1k4@gmail.com
}

\begin{abstract}
Hypertension is defined as a continuous increase in arterial blood pressure. In 2013 nationally $25.8 \%$ of Indonesia's population suffered from hypertension. Hypertension can be reduced by additional therapy such as consuming fruits containing potassium. Kepok bananas contain high potassium. This study aims to look at the characteristics of age, sex, smoking habits and disease history of geriatric hypertension respondents and the effect of giving kepok banana juice to blood pressure reduction in geriatric hypertension patients at the UPTD of the Social Institution of Tresna Werdha Nirwana Puri Samarinda. The research method used was the experimental quasi method with pre and post test research procedures. Characteristic data collection was done retrospectively with the results of the percentage of characteristics based on gender being women as much as 57.14\%. The highest age characteristics were 75-90 years as many as $71.43 \%$, while those who did not have smoking habits were $64.29 \%$. The history of other diseases suffered include gout, allergic dermatitis, myalgia, cholesterolemia, diabetes and asthma with the highest percentage being myalgia of $31.82 \%$. The results of the descriptive analysis of kepok banana juice were in line with the statistical analysis of the paired sample t-test method which had a $p$ value <0.05, meaning kepok banana juice was able to reduce blood pressure significantly both systolic and diastolic blood pressure.
\end{abstract}

Keywords: Kepok Banana; blood pressure; experimental quasi; potassium

\begin{abstract}
ABSTRAK
Hipertensi didefinisikan sebagai kejadian meningkatnya tekanan darah arteri secara terus menerus. Tahun 2013 secara nasional 25,8\% penduduk Indonesia menderita penyakit hipertensi. Hipertensi dapat diturunkan dengan terapi tambahan seperti mengkonsumsi buah-buahan yang mengandung kalium. Pisang kepok mengandung kalium yang tinggi. Penelitian ini bertujuan untuk melihat karakteristik usia, jenis kelamin, kebiasaan merokok serta riwayat penyakit dari responden hipertensi geriatrik dan pengaruh pemberian jus pisang kepok terhadap penurunan tekanan darah penderita hipertensi geriatrik di UPTD Panti Sosial Tresna Werdha Nirwana Puri Samarinda. Metode penelitian yang digunakan adalah metode quasi eksperimental dengan prosedur penelitian pre dan post test. Pengumpulan data karakteristik dilakukan dengan retrospektif dengan hasil persentase karakteristik berdasakan jenis kelamin ialah perempuan sebanyak 57,14\%. Karakteristik
\end{abstract}


usia tertinggi yaitu 75-90 tahun sebanyak 71,43\%, sedangkan yang tidak memiliki kebiasaan merokok sebanyak $64,29 \%$. Riwayat penyakit lain yang diderita antara lain asam urat, dermatitis alergi, myalgia, kolesterolemia, diabetes dan asma dengan persentase tertinggi ialah myalgia sebesar $31,82 \%$. Hasil analisis deskriptif jus pisang kepok sejalan dengan analisis statistik metode paired sample t-test yang memiliki nilai $p$ value $<0,05$ artinya jus pisang kepok mampu menurunkan tekanan darah secara signifikan baik tekanan darah sistolik maupun diastolik.

Kata Kunci : Pisang Kepok; tekanan darah; quasi eksperimental; kalium

DOI: https://doi.org/10.25026/mpc.v8i1.329

\section{PENDAHULUAN}

Hipertensi adalah keadaan tekanan darah sistolik lebih dari 140 $\mathrm{mmHg}$ dan tekanan diastolik lebih dari $90 \mathrm{mmHg}$. Penduduk Amerika yang berusia diatas 20 tahun menderita hipertensi telah mencapai angka hingga 74,5 juta jiwa, namun hampir sekitar 9095\% kasus tidak diketahui penyebabnya. ${ }^{1}$ Secara nasional tahun 2013 sebanyak $25,8 \%$ penduduk Indonesia menderita penyakit hipertensi. Sehingga jika jumlah penduduk Indonesia sebesar 252.124.458 jiwa maka terdapat 65.048.110 jiwa yang menderita hipertensi. Suatu kondisi yang cukup mengejutkan. Terdapat 13 provinsi yang persentasenya melebihi angka nasional, dengan tertinggi di Provinsi Bangka Belitung (30,9\%) atau secara absolut sebanyak 30,9\% x 1.380 .762 jiwa $=426.655$ jiwa. $^{2}$

Usia merupakan salah satu faktor yang mempengaruhi tekanan darah. Semakin tua seseorang maka semakin besar resiko terserang hipertensi. ${ }^{3}$ Pada lansia dibanding usia 55-59 tahun dengan usia 60-64 tahun terjadi peningkatan risiko hipertesi sebesar 2,18 kali, usia 6569 tahun 2,45 kali dan usia $>70$ tahun 2,97 kali. ${ }^{4}$ Hal ini terjadi karena pada usia tersebut arteri besar kehilangan kelenturannya dan menjadi kaku karena itu darah pada setiap denyut jantung dipaksa untuk melalui pembuluh darah yang sempit daripada biasanya dan menyebabkan naiknya tekanan darah. ${ }^{5}$

Perawatan pasien hipertensi dapat dilakukan dengan cara memodifikasi gaya hidup. Perawatan dengan memodifikasi gaya hidup antara lain dengan mengkonsumsi makanan yang rendah garam dan rendah lemak, serta mengkonsumsi buah-buahan. Direkomendasikan mengkonsumsi kalium untuk menurunkan tekanan darah dan resiko penyakit kardiovaskuler, stroke, dan penyakit jantung koroner. ${ }^{6}$ Intake kalium berpengaruh pada pembuluh darah yaitu kalium akan menurunkan resistensi pembuluh darah perifer yang secara langsung dapat melebarkan arteri, peningkatan pengeluaran air dan natrium dari tubuh, penekanan sekresi renin angiotensin, dan stimulasi dari aktivitas pompa natriumkalium. ${ }^{7}$ Kalium yang yang tinggi juga dapat meningkatkan vasodilatasi endotelium yang kemudian menurunkan konsentrasi kalsium intraseluler akibatnya menurunkan kontraksi otot polos dan tekanan darah sistolik. ${ }^{8}$ Resistensi perifer yang terjadi karena adanya asupan kalium akan mengakibatkan pembuluh darah arteri dan vena terkonstriksi, sehingga tekanan darah diastol menjadi normal. ${ }^{9}$

Pisang merupakan salah satu buah yang dapat dijadikan alternatif dalam melakukan diet makanan sebagai upaya 
penurunan tekanan darah. ${ }^{6}$ Penelitian mengenai pengaruh pisang pada penderita hipertensi sebelumnya telah ada, yaitu dengan menggunakan pisang ambon dengan kandungan kaliumnya yang dapat menurunkan tekanan darah. Sebuah jurnal yang membandingkan kandungan pada beberapa jenis pisang salah satunya kandungan kalium mengatakan bahwa pisang kepok memiliki jumlah kalium yang lebih tinggi dibanding dengan jumlah kalium pada pisang ambon dan pisang raja. Kandungan kalium pada pisang kepok sebesar $365 \mathrm{mg} / 100 \mathrm{~g} .{ }^{10}$ Jurnal lain yang membuktikan adanya pengaruh pemberian jus belimbing pada penurunan tekanan darah juga menyebutkan bahwa jus belimbing dapat menurunkan tekanan darah dengan salah satu kandungannya yang berperan dalam menurunkan tekanan darah yaitu kalium. ${ }^{11}$ Kandungan kalium pada belimbing sebesar $133 \mathrm{mg} / 100 \mathrm{~g}$ belimbing. ${ }^{12}$

Berdasarkan latarbelakang tersebut maka perlu dilakukan penelitian untuk mengetahui karakteristik responden hipertensi geriatrik di UPTD Panti Sosial Tresna Werdha Nirwana Puri Samarinda dan melihat potensi buah pisang kepok dalam menurunkan tekanan darah responden hipertensi geriatrik di UPTD Panti Sosial Tresna Werdha Nirwana Puri Samarinda.

\section{METODE PENELITIAN}

\section{Alat dan Bahan}

Alat yang digunakan ialah blender, timbangan, penyaring, botol minum, gelas ukur $250 \mathrm{~mL}$, sendok, pisau, dan tensimeter manual. Bahan yang digunakan ialah pisang kepok, air mineral, lembar informed consent, lembar data rekam medik, dan tisu.

\section{Populasi dan Sampel Penelitian}

Populasi dalam penelitian ini adalah penderita hipertensi geriatrik di UPTD Panti Sosial Tresna Werdha
Nirwana Puri Samarinda. Metode sampling penelitian ini ialah dengan teknik purposive sampling. Pemilihan responden didasarkan atas kriteria inklusi responden yaitu responden yang masuk dalam daftar penderita hipertensi berdasarkan data yang diperoleh dari klinik, dapat berkomunikasi baik secara verbal maunpun non verbal, dan tidak memiliki komplikasi penyakit yang serius apabila diberikan perlakuan penelitian serta menyatakan bersedia menjadi responden penelitian dengan menandatangi formulir informed consent. Penderita hipertensi geriatrik yang memenuhi kriteria inklusi dinyatakan sebagai responden penelitian.

\section{Desain Penelitian}

Rancangan penelitian ini ialah quasi eksperimental dengan desain penelitian pre test and post test with control design. Penelitian ini dilakukan bulan Juli - Agustus 2018. Variabel independen penelitian ini adalah buah pisang kepok, sedangkan variabel dependen yaitu penurunan tekanan darah responden hipertensi geriatrik. Data karakteristik dalam penelitian ini diperoleh secara retrospektif melalui wawancara dan dari data yang tersedia di klinik panti tersebut. Data pengukuran tekanan darah sebelum dan sesudah pemberian jus pisang kepok dilakukan secara prospektif dengan metode analisis hasil data dilakukan secara deskriptif dan uji statistik paired sample t-test.

Responden yang memenuhi kriteria inklusi dibagi kedalam dua kelompok, yaitu kelompok yang diberikan jus pisang kepok dan kelompok yang tidak diberi jus pisang kepok. Kelompok perlakuan akan diberikan jus yang mengandung pisang kepok 200 gram sebanyak dua kali sehari pagi dan sore selama 7 hari. Responden di ukur tekanan darahnya pagi sebelum perlakuan dan sore 30-60 menit setelah perlakuan. Dicatat data yang diperoleh, kemudian dilakukan analisis deskriptif dan statistik 
dengan metode analisis paired_sample test.

\section{HASIL DAN PEMBAHASAN}

Hasil penelitian yang dilakukan pada bulan Juli - Agustus 2018 diperoleh data dari 14 orang responden. Pada tabel 1 diperoleh data karakteristik di UPTD Panti Sosial Tresna Werdha Nirwana Puri Samarinda yaitu berdasarkan usia hipertensi pada lansia terjadi paling banyak diusia 75-90 tahun, oleh perempuan dan persentase responden yang tidak memiliki kebiasaan merokok lebih besar daripada yang memiliki kebiasaan merokok. Hasil persentase data dapat dilihat pada tabel 1 .

Tabel 1. Data Karakteristik Responden di UPTD Panti Sosial Tresna Werdha Nirwana Puri Samarinda

\begin{tabular}{lll}
\hline \multicolumn{2}{c}{ Karakteristik } & Persentase \\
\hline \multirow{2}{*}{ Usia } & 60-74 tahun & $28,57 \%$ \\
& 75-90 tahun & $71,43 \%$ \\
\hline \multirow{2}{*}{ Jenis Kelamin } & Perempuan & $57,14 \%$ \\
& Laki-laki & $42,86 \%$ \\
\hline \multirow{2}{*}{ Kebiasaan } & Merokok & $35,71 \%$ \\
Merokok & Tidak Merokok & $64,29 \%$ \\
\hline
\end{tabular}

Usia lansia dibagi menjadi 4 kelompok yaitu usia pertengahan (middle age) 45-59 tahun, usia lanjut (ederly) 6074 tahun, lansia tua (old) 75-90 tahun dan lansia sangat tua (very old). ${ }^{13}$ Meningkatnya angka hipertensi terbukti berkaitan dengan seiring bertambahnya usia. Ada beberapa faktor yang berperan pada usia lanjut yaitu terjadinya penurunan kadar renin karena menurunnya jumlah nefron akibat proses menua, peningkatan sensitivitas terhadap asupan natrium dimana semakin lanjutnya usia maka semakin sensitif terhadap peningkatan atau penurunan kadar natrium dan penurunan elastisitas pembuluh darah perifer. ${ }^{14}$ Berdasarkan teori tersebut maka dapat dikatakan bahwa bertambahnya usia akan meningkatkan risiko terjadinya hipertensi.

Hormon estrogen mempunyai fungsi mencegah kekentalan darah serta menjaga dinding pembuluh darah agar tetap baik. Responden lanjut usia tentu berada pada fase menopause. Ovarium perempuan pada fase ini akan mengalami penurunan fungsi yang berakibat pada berkurangnya jumlah hormon estrogen yang dihasilkan. ${ }^{15}$ Tingginya hipertensi pada perempuan dibanding laki-laki juga dapat dikarenakan faktor stres. Otak perempuan memiliki kewaspadaan yang negatif terhadap adanya konflik dan stress. Pada perempuan konflik memicu hormon kortisol sehingga memunculkan stres, gelisah, dan rasa takut. Dengan kata lain, ketika perempuan mendapat tekanan, maka umumnya akan lebih mudah mengalami stress. ${ }^{16}$ Adanya stimulus stres yang diterima oleh hipotalamus akan mengaktifkan sistem saraf simpatis dan parasimpatis sehingga terjadi peningkatan frekuensi jantung. Perangsangan saraf simpatis juga mengakibatkan aktivasi dari medula adrenalis yang menyebabkan pelepasan epinefrin dan norepinefrin ke dalam darah dan ini akan meningkatkan tekanan darah dan frekuensi nadi. ${ }^{17}$ Sehingga dapat dikatakan bahwa jenis kelamin memiliki keterkaitan dengan kejadian hipertensi, dimana perempuan terbukti memilik risiko yang lebih tinggi terkena hipertensi.

Tiap rokok mengandung kurang lebih 4000 bahan kimia, dan hampir 200 diantaranya beracun dan 43 jenis yang dapat menyebabkan kanker bagi tubuh. Racun utama pada rokok adalah nikotin. Komponen ini paling banyak dijumpai di dalam rokok. Nikotin yang ada di dalam rokok dapat mempengaruhi tekanan darah seseorang, bisa melalui pembentukan plak aterosklerosis, efek langsung nikotin terhadap pelepasan hormon epinefrin dan norepinefrin, ataupun melalui efek $\mathrm{CO}$ 
dalam peningkatan sel darah merah. ${ }^{18}$ Kandungan $\mathrm{CO}$ dalam rokok mempunyai kemampuan mengikat hemoglobin dalam sel darah merah, lebih kuat dibandingkan oksigen, sehingga setiap ada asap tembakau, disamping kadar oksigen udara yang sudah berkurang, ditambah lagi sel darah merah akan semakin kekurangan oksigen karena yang diangkut adalah karbon monoksida dan bukan oksigen. ${ }^{19}$ Berdasarkan teori tersebut hasil penelitian ini tidak sejalan dengan teori yang ada, yaitu seharusnya angka kejadian merokok meningkat sejalan dengan meningkatnya jumlah penderita hipertensi. Hal ini dapat dikarenakan responden penderita hiperten pada penelitian memiliki persentase yang lebih tinggi untuk jenis kelamin perempuan dibandingkan laki-laki.

Berdasarkan Tabel 2 diperoleh data bahwa pada responden penderita hipertensi geriatrik di UPTD Panti Sosial Tresna Werdha Nirwana Puri Samarinda paling banyak mengalami myalgia atau nyeri otot dari 5 riwayat penyakit lainnya. Lima riwayat penyakit lainnya yaitu asam urat, dermatitis alergi, kolesterolemia, diabetes melitus dan asma.

Tabel 2. Distribusi Jumlah Responden Berdasarkan Riwayat Penyakit

\begin{tabular}{ll}
\hline Riwayat penyakit & Persentase \\
\hline Myalgia & $31,82 \%$ \\
Dermatitis alergi & $13,64 \%$ \\
Asam urat & $13,64 \%$ \\
Kolesterolemia & $9,09 \%$ \\
Diabetes melitus & $9,09 \%$ \\
Asma & $9,09 \%$ \\
Tanpa riwayat penyakit & $4,55 \%$ \\
\hline
\end{tabular}

Proses menua mengakibatkan terjadinya penurunan fungsi dari organorgan lansia, diantaranya penurunan penglihatan, kemunduran sel saraf, penurunan fungsi muskuloskeletal, dan penurunan massa otot yang dapat menyebabkan gangguan pada otot, salah satunya adalah myalgia atau nyeri otot. ${ }^{20}$ Penyebab umum myalgia adalah penggunaan otot yang salah atau otot yang terlalu tegang akhirnya akan mengalami kekurangan oksigen, sehingga terjadi suatu proses oksidasi anaerob yang akan menghasilkan asam laktat. Asam laktat inilah yang akan menimbulkan rasa pegal atau nyeri. Lansia merupakan tahap akhir siklus kehidupan. Lansia adalah kelompok orang yang sedang mengalami suatu proses perubahan yang bertahap dalam jangka waktu beberapa dekade. Pada tahap ini individu mengalami banyak perubahan baik secara fisik maupun mental, khususnya kemunduran dalam berbagai fungsi dan kemampuan yang pernah dimilikinya. ${ }^{21}$ Populasi lansia di kawasan Asia Tenggara mencapai 8\% atau sekitar 142 juta jiwa. Pada tahun 2011 jumlah penduduk lansia di Indonesia sekitar 18,27 juta orang atau $7,58 \%$ dari total penduduk. ${ }^{22}$ Berdasarkan teori tersebut maka bertambahnya usia berbanding lurus dengan menurunnya kemampuan dan fungsi organ.

Hasil pengukuran tekanan darah kelompok yang tidak diberi jus pisang kepok, diperoleh responden mengalami kenaikan tekanan darah sistolik (gambar 1) yaitu $\mathrm{R} 14,28 \mathrm{mmHg}$; $\mathrm{R} 22,85 \mathrm{mmHg}$; R3 7,14 mmHg; R4 4,28 mmHg; R5 2,86 mmHg; R6 4,28 dan R7 7,14. Tekanan darah diastol (gambar 2) juga mengalami peningkatan yaitu R1 2,86 $\mathrm{mmHg}$; R2 11,43 mmHg; R3 1,43 mmHg; R4 4,29 $\mathrm{mmHg}$; R5 5,71 mmHg; R6 1,43 mmHg; dan R7 5,72 mmHg.

Hasil pengukuran tekanan darah (gambar 3) kelompok pemberian jus pisang kepok sebagai antihipertensi menunjukkan hasil bahwa responden mengalami penurunan tekanan darah sistolik, masing-masing R1 7,13 mmHg; R2 8,58 mmHg; R3 $10 \mathrm{mmHg}$; R4 1,43 $\mathrm{mmHg}$; R5 11,43 mmHg; R6 17,14 $\mathrm{mmHg}$ dan R7 7,14 mmHg. Hasil 
pengukuran tekanan darah diastolik (gambar 4) mengalami penurunan R1 $8,57 \mathrm{mmHg}$; R2 1,43 mmHg; R3 8,57
mmHg; R4 1,43 mmHg; R5, R6, R7 masing-masing sebesar $4,28 \mathrm{mmHg}$.

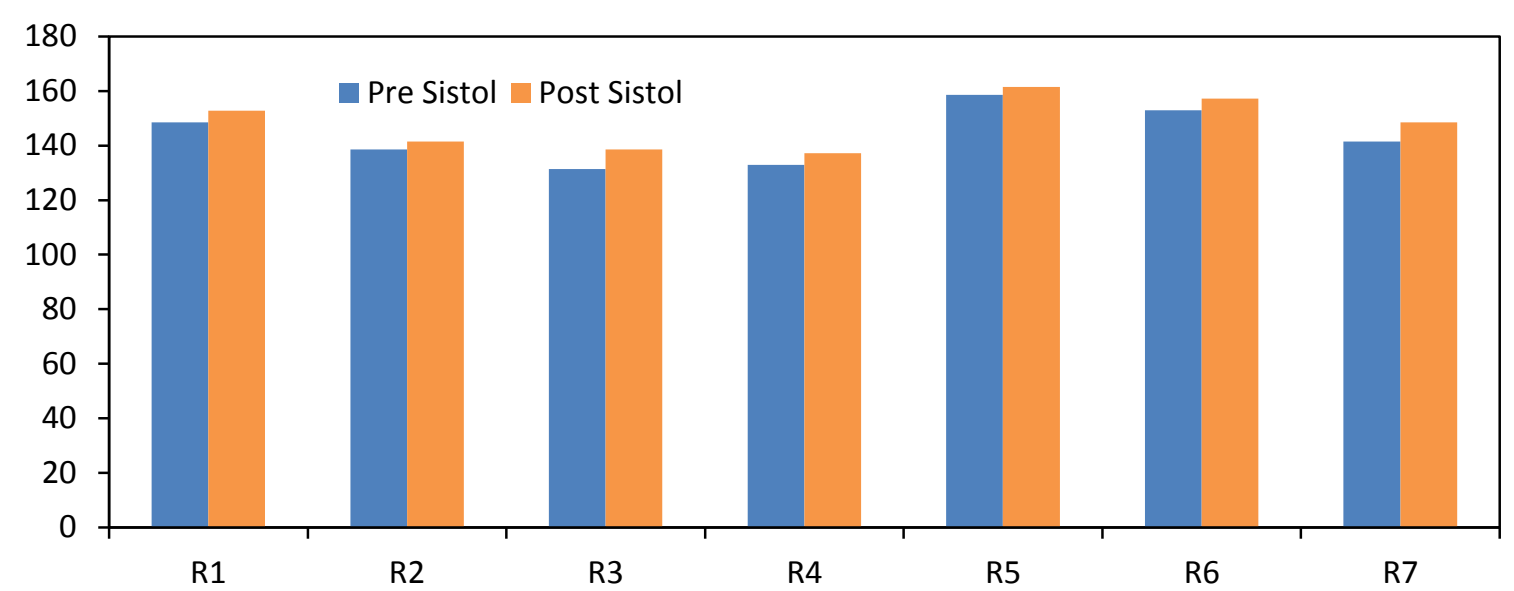

Gambar 1. Hasil Pengukuran Tekanan Darah Sistolik Responden Kelompok Yang Tidak diberikan Jus Pisang Kepok

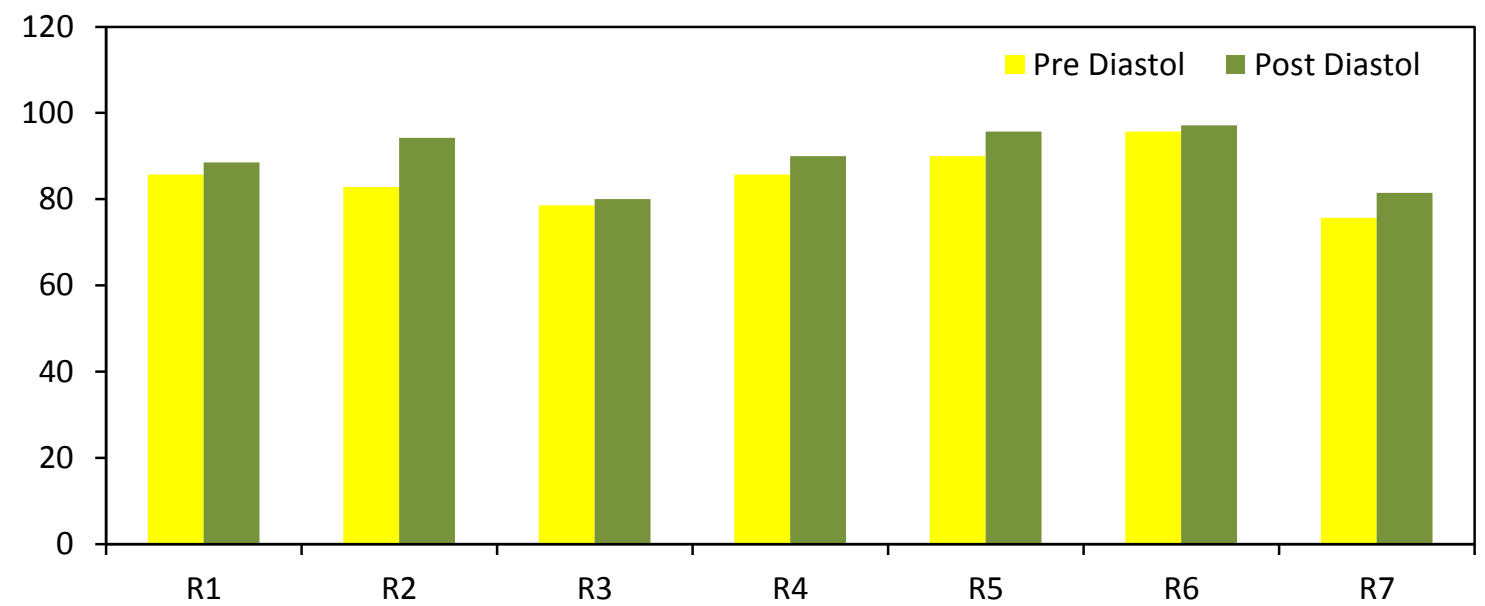

Gambar 2. Hasil Pengukuran Tekanan Darah Diastolik Responden Kelompok Yang Tidak diberikan Jus Pisang Kepok 


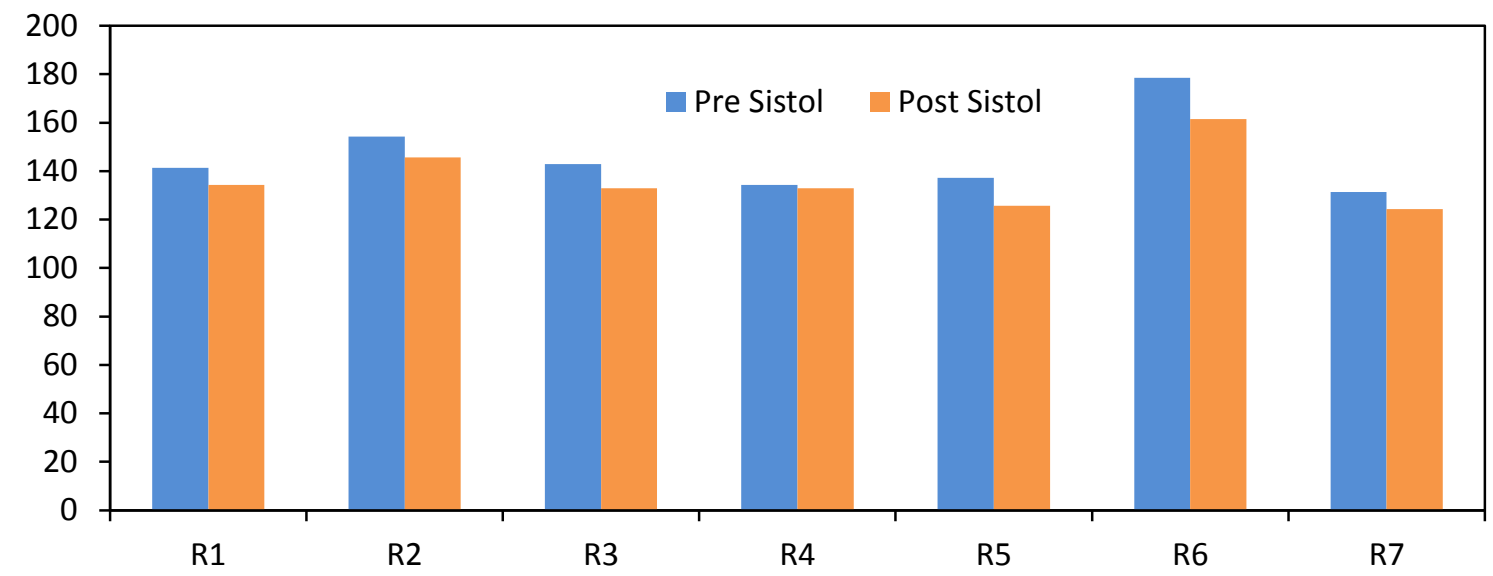

Gambar 3. Hasil Pengukuran Tekanan Darah Sistolik Responden Kelompok Pemberian Jus Pisang Kepok

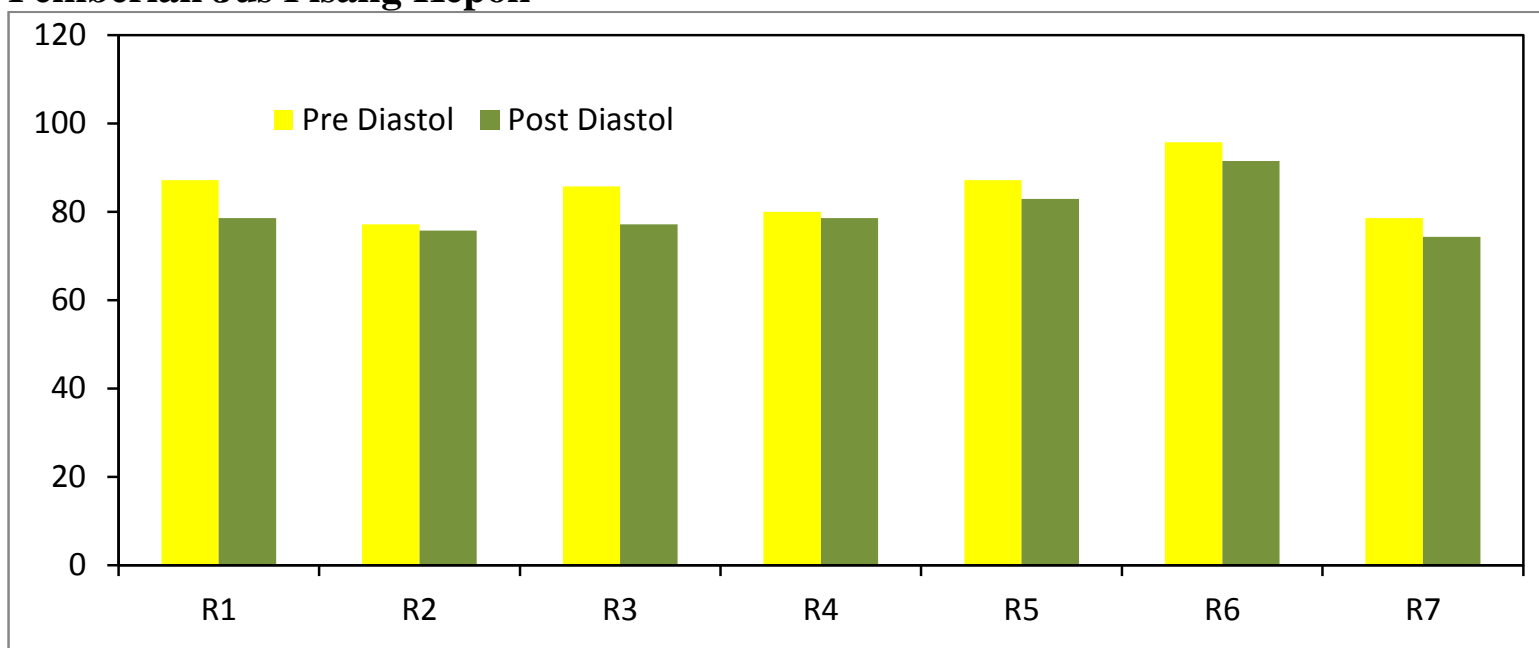

Gambar 4. Hasil Pengukuran Tekanan Darah Diastolik Responden Kelompok Pemberian Jus Pisang Kepok

Berdasarkan hasil pengukuran tekanan darah baik sistolik maupun diastolik antara kelompok yang diberikan jus pisang kepok dengan kelompok yang tidak diberikan jus pisang kepok terlihat bahwa pada kelompok responden yang tidak diberikan jus pisang kepok tidak mengalami penurunan tekanan darah baik sistolik maupun diastolik, sedangkan kelompok responden yang diberikan jus pisang kepok mengalami penurunan tekanan darah. Adanya penurunan tekanan darah setelah responden diberikan jus pisang kepok membuktikan bahwa kandungan kalium pada pisang kepok memiliki pengaruh dalam menurunkan tekanan darah.
Pisang adalah buah yang mengandung kalium tinggi. Kalium dapat menjaga kesehatan kardiovaskuler dengan cara mengontrol aktivitas elektrik jantung dan menurunkan tekanan darah, khususnya bagi yang memiliki resiko atau sedang mengalami peningkatan tekanan darah. Dari beberapa jenis pisang, diperoleh kandungan kalium pada pisang kepok sebesar $365 \mathrm{mg} / 100 \mathrm{~g}$ yaitu lebih tinggi dibanding kalium pada pisang ambon dan pisang raja ${ }^{7}$ Peran ion kalium terhadap penurunan tekanan darah ialah sebagai vasodilator, karena kemampuannya dalam menghambat kontraksi otot polos dan pembuluh darah. 
Kalium juga menghambat reabsorpsi natrium ditubulus ginjal. ${ }^{23}$

Kandungan kalium pada pisang dapat menurunkan tekanan darah sistolik dengan cara menghambat pelepasan renin dan berfungsi sebagai katalisis penguraian angiotensin menjadi angiotensin I. Angiotensin I berubah menjadi angiotensin II dengan bantuan Angiotensin Converting Enzyme (ACE). Angiotensin II kemudian merangsang pengeluaran aldosteron yang mengakibatkan tekanan darah meningkat dengan cara meretensi natrium. Adanya kandungan kalium dalam jus pisang kepok dapat menurunkan retensi natrium dan air kemudian volume plasma berkurang, curah jantung, dan tekanan perifer. ${ }^{24}$ Dengan menghambat pelepasan renin-angiotensin kalium mempunyai efek natriuretik yang dapat meningkatkan ekskresi air dan natrium sehingga dapat menurunkan volume plasma hinggan tekanan darah menurun. ${ }^{25}$ Kandungan kadar kalium yang tinggi serta natrium yang rendah sebagai obat anti hipertensi. Tingginya asupan kalium akan mampu menurunkan produksi atau sekresi hormon antideuretik (ADH) dan rasa haus. Hormon ini bekerja pada ginjal untuk mengatur osmolaritas dan volume urine. Menurunnya ADH dapat mengakibatkan peningkatan ekskresi urine keluar tubuh. Darah menjadi encer dengan osmolaritas yang rendah dan kepekatan cairan intraseluler maupun ekstraseluler dapat diseimbangkan kemudian menurunkan konsentrasi $\mathrm{NaCl}$ yang selanjutnya berefek pada penurunan tekanan darah. ${ }^{26}$ Asupan kalium yang yang tinggi juga dapat meningkatkan vasodilatasi endotelium yang kemudian menurunkan konsentrasi kalsium intraseluler akibatnya menurunkan kontraksi otot polos dan tekanan darah sistolik. ${ }^{27}$
Tabel 3. Hasil Analisis Sampel T Berpasangan Tekanan Darah Sistolik dan Diastolik Pre dan Post Test Kelompok Pemberian Jus Pisang Kepok

\begin{tabular}{ccc}
\hline $\begin{array}{c}\text { Tekanan } \\
\text { Darah }\end{array}$ & $\begin{array}{c}\text { Jumlah } \\
\text { Responden }\end{array}$ & $p$ Value \\
\hline Sistol & 7 & 0.003 \\
Diastol & 7 & 0.006 \\
\hline
\end{tabular}

\begin{abstract}
Berdasarkan hasil analisis statistik dengan metode analisis sampel berpasangan (tabel 3) diperoleh nilai $p$ value yaitu 0,003 untuk tekanan darah sistol dan 0,006 untuk tekanan darah diastolik. Hal ini menunjukkan nilai $p$ value $<0,05$ sehingga dapat dikatakan bahwa pemberian jus pisang kepok berpengaruh secara signifikan terhadap penurunan tekanan darah baik sistolik maupun diastolik.
\end{abstract}

\section{KESIMPULAN}

1. Gambaran karakteristik responden diperoleh data bahwa hipertensi pada lansia terjadi paling banyak diusia 7590 yaitu $71,43 \%$, perempuan lebih banyak mengalami hipertensi dengan persentase $57,14 \%$, kemudian sebanyak 64,29\% responden tidak memiliki kebiasaan merokok, dan riwayat penyakit yang paling banyak diderita oleh responden hipertensi geriatrik ialah myalgia yaitu sebesar $31,82 \%$.

2. Pemberian jus pisang kepok sebagai antihipertensi memiliki pengaruh dalam menurunkan tekanan darah dengan nilai $p$ value uji sampel $\mathrm{t}$ berpasangan yaitu 0,003 untuk tekanan darah sistol dan 0,006 untuk tekanan darah diastol.

\section{UCAPAN TERIMAKASIH}

Terimakasih kepada UPTD. Panti Sosial Tresna Werdha Nirwana Puri Samarinda yang telah membantu dalam penelitian ini. 
DAFTAR PUSTAKA

[1] American Heart Association (AHA). 2016. Ejection Fraction Heart Failure: American.

[2] Kementrian Kesehatan RI. 2014. Hipertensi. Badan Penelitian dan Pengembangan Kesehatan Kementrian Kesehatan RI: Jakarta.

[3] Khomsan, A. 2003. Pangan dan Gizi Untuk Kesehatan. PT. Rajagrafindo Persada. Jakarta.

[4] Rahajeng, E., Tuminah, S. 2009. Prevalensi Hipertensi dan Determinannya di Indonesia. Majalah Kedokteran Indonesia.

[5] Sigarlaki, HJO. 2006. Karakteristik Dan Faktor Berhubungan Dengan Hipertensi Di Desa Bocor, Kecamatan Bulus Pesantren, Kabupaten Kebumen, Jawa Tengah. Makara, Kesehatan.

[6] Organization World Health. 2013. A global brief on Hypertension: silent killer, global public health crises. WHO: Geneva.

[7] Blackburn GL. 2014. Functional Food in the Prevention and Treatment of Desease: Significance of the Dietary Approaches to Stop Hypertension Study. Am J Clin Volume 3, Nomor 4

[8] Kumala, M. 2014. Peran Diet dalam Pencegahan dan Terapi Hipertensi. Damianus, Jurnal of Medicine, 13(1). 50-61.

[9] Raharjo, P. 2010. Pengaruh Pemberian Jus Tomat Terhadap Perubahan Tekanan Darah Sistolik dan Diastolik pada Penderita Hipertensi di Desa Wonorejo Kecamatan Lawang Malang. Jurnal Keperawatan ISSN : 2086-3071. 5-6

[10]Lia Hapsari adn Dwi Ayu Lestari. 2016. Fruit Characteristic And Nutrient Values Of Four Indonesian Banana Cultivars ( Musa spp. ) At Different Genomic Groups. Agrivita Journal Of Agricultural Science 303301; Indonesian Institute Science.
[11]Retno Safitri, Aryu Candra. 2015. Pengaruh Pemberian Jus Belimbing Wuluh Terhadap Penurunan Tekanan Darah Sistolik Tikus Sprague Dawley. Journal of Nutrition College, Volume 4, Nomor 2 Halaman 541-546

[12] Antia Devi Iralawati1 dkk. 2012. Jus Belimbing Manis (Averrhoa carambola L.) Sebagai Hepatoprotektor Pada Tikud (Rattus novergicus strain wistar) Yang Diinduksi Antituberkulosis Rifampisin Dan Isoniazid. Jurnal Fakultas Kedokteran Universitas Muhammadiyah Malang volume 8 no 2

[13] Organization World Health. 2013. A global brief on Hypertension: silent killer, global public health crises. WHO: Geneva.

[14]Boedhi, Darmojo, R. 2011. Buku Ajar Geriatic (Ilmu Kesehatan Lanjut Usia) edisi ke-4. Balai Penerbit FKUI: Jakarta.

[15]Manurung, Nixson., dkk. 2017. Asuhan Keperawatan Sistem Endokrin Dilengkapi Mind Mapping dan Asuhan Keperawatan Nanda Nic Noc. Deepublish: Yogyakarta

[16]Brizendine L. 2007. The Female Brain. Penerjemah: Meda Satrio. Ufuk Press : Jakarta.

[17] Greenberg, Jerrrold S. 2002. Comprehensive Stress Management 7th edition. New York : McGrawHill Companies, Inc.

[18]Khoirudin. 2005. Perbedaan kapasitas vital paru dan tekanan darah antara perokok aktif dengan perokok pasif pada siswa Madrasah Hidayatul Mubtadi'in Semarang Tahun Ajaran 2005/2006. Semarang: Fakultas Ilmu Keolahragaan Universitas Negeri: Semarang.

[19] Sitepoe, Mangku. 2000.Usaha mencegah bahaya merokok. Gramedia: Jakarta.

[20]Darmojo B. 2009. Buku ajar Geriatri (Ilmu Kesehatan Usia Lanjut). Balai 
Penerbit Fakultas Kedokteran Universitas Indonesia: Jakarta.

[21] Soejono. 2000. Pedoman Pengelolaan Kesehatan Pasien Geriatric untuk Dokter dan Perawat. FK UI, 60-76: Jakarta.

[22]Badan Pusat Statistik (BPS). 2012. Data Statistik Indonesia: Jumlah Penduduk menurut Kelompok Umur, Jenis Kelamin, Provinsi, dan Kabupaten/Kota: Indonesia.

[23] Graner, Daryl K., Murray, Robert K. 2012. Biokimia Harper Edisi 29. Penerbit Buku Kedokteran EGC: Jakarta.

[24] Kotchen AK, Kotchen J, dkk. 2006. Modern Nutrition In Health Desease.10th ed. : Philadelphia
[25] Kumala, M. 2014. Peran Diet Dalam Pencegahan Dan Terapi Hipertensi. Damianus Journal Of Medicine Vol 13 No. 1.

[26] Muniroh Lailatul, et al. 2006. Pengaruh Pemberian Jus Buah Belimbing dan Mentimun terhadap Penurunan Tekanan Darah Sistolik dan Diastolik Penderita Hipertensi', The Indonesian Journal Of Public Health, vol. 4, no. 1, juli 2007: 2534.

[27] Kumala, M. 2014. Peran Diet Dalam Pencegahan Dan Terapi Hipertensi. Damianus Journal Of Medicine Vol 13 No. 1. 